\title{
Effect of Proline, Methyl Salicylate, and Magnetic Field in the Salinity of Vegetative, Flowering Growth, Chemical Composition and Oil Content on Viola odorata, Linn.
}

\author{
Mohamed, Safaa M¹.; EmanM.Abou El-ghit; Y.Ghatas,Hammam K. and Aml. Shahin² \\ ${ }^{1}$ Horticulture, Dpt. Fac. Of Agri., Benha University. \\ ${ }^{2}$ Horticulture, Research Institute, Agriculture Research Center.
}

\begin{abstract}
This experiment was carried out during two consecutive seasons of 2016/2017 and 2017/2018 in the experimental farm of horticulture department, Faculty of Agriculture Moshtohor Benha university, Egypt, to study alleviation of salinity stress on vegetative and flowering growth, chemical composition and essential oil of viola plants. By using the chemical method as a foliar spray of (proline and methyl salicylate (Me Sa)) and magnetic field as modern technology and friendly to the environment under saline conditions. Results revealed that Irrigation of Viola odorataLinn. With saline water resulted in a significant reduction in vegetative growth and flowering growth, root characters, consequently Percentage of concrete on flowers and leaves. /plant. but using methyl salicylate and proline showed less reduction in the growth of vegetative and flowering, root characters, consequently Percentage of concrete on flowers and leaves/plant. Under the same condition of saline. Magnetic field gave the best results.
\end{abstract}

Keywords: viola odorata, proline,(Me Sa) magnetic field,

\section{Introduction}

Viola odorata L. belongs to family Violaceae. It is commonly known as Sweet Violet, English Violet, Common Violet or Garden Violet. Violet plant is a native of Mediterranean countries and Asia Minor and now it has spread to most of Europe. The plant is a perennial herb, spreading with stolon's (aboveground shoots). Leaves are orbicular-reniform to broadly ovate. Flowers have dark violet color. Azadeh Foroughi1 et al., (2016)

The herb is well known for its Pharmaceutical importance in Ayurvedic and Unani medicinal system. It is used for the treatment of whooping cough. Its drug is also anti-inflammatory, diaphoretic, diuretic, emollient, expectorant, antipyretic and laxative. It contains salicylic acid which is used to make aspirin hence effective for the treatment of headaches, migraine, and insomnia. The roots of the plant yield an alkaloid violin which is used as an expectorant. Sweet violet is used for the treatment of bronchitis, common digestive disorders, postoperative tumor metastasis, diabetes, and cancer. Payal Mitta et al., (2015)

In saline lands where salinity reduce agriculture area, the search for new crop, cultivation is interesting in agricultural research. Salt tolerant plants can be used to produce economically important materials such as antioxidants and essential oils. Environmental condition and genetic influence plants secondary products Aziz Eman et al., (2008) So, the development of new tools and strategies to evaluate the combination of water and salt stress on plant are also necessary we investigated the effect of salt stress on Viola odorata L. to cultivation this plant at the saline area and better landscape use in Egypt.

Proline function as compatible solutes and are up regulated in plants under abiotic stress. They play an osmo protective role in physiological responses, enabling the plants to better tolerate the adverse effects of abiotic stress. Exogenous application of proline considered as an important agent to maintain osmotic potential of the plant cell Ali et al., (2007). it considered as an antioxidant agent through its role in increasing the ability of plant to tolerate salt stress. Okumaet al, (2004).

salicylic acid (SA) play a critical role in the regulation of plant growth, development, and interaction with other organisms and defense responses to environmental stresses Bastamet al., (2013) Major role of SA in plant is thought to be the regulation of responses to biotic stresses. it is also involved in responses to several abiotic stresses including salt stress Iqbal et al., (2014) SA is also converted to methyl salicylate (MeSA) by a SA carboxyl methyltransferase Vlotet al., (2008) methyl salicylate (MeSA) is known to be released by stressed plants. It is a signal involved in eliciting plant resistance to stressors such as salinity (Fung et a.l, (2004).

prospect of using magnetic technologies in agriculture is not a new concept, Magnetic technology can become a useful tool, as proved by many researchers, to tackle problems related to reduced crop productivity due to the use of saline water in agriculture. Ashwini H. Gudigar (2013) The magnetic field may provide a feasible nonchemical solution in agriculture. At the same time, it offers advantages to protect environment and safety 
for the applicator.K.N.Guruprasadet al., (2014)It has been reviewed that the positive effect of magnetic treatment may be attributed to paramagnetic properties of some atoms in plant cells and some pigments such as chloroplasts . Magnetic properties of molecules determine their ability to attract and then change the energy of a magnetic field in other types of energy and to transfer this energy to other structures in plant cells, thus activating them Aladjadjiyan, A, (2010.) Magnetic field play an important role in cation uptake capacity and have a positive effect on immobile plant nutrient uptake, such as $\mathrm{Ca}$ and $\mathrm{Mg}$ Esitken and Turan (2004).

Thus, the present study was conducted to evaluate the response of viola odorata $\mathbf{L}$. to prolin, methyl salicylate and magnetic treatments under salt stress.

\section{Material and Methods}

The present study was conducted during two successive seasons of 2016/2017 and 2017/2018 seasons at the Experimental Farm, of the Faculty Agriculture (Moshtoher), Benha University, Egypt. on viola (Viola odorata Linn.) plants.

\section{Plant Materials}

Offsets of violets (Viola odorata Linn.) were obtained from Horticulture Department, Faculty of Agriculture, Benha University, Egypt. The average plant height was 8 to $10 \mathrm{~cm}$ and number of leaves were 5.8 leaf.

\section{Experimental procedure}

- The offsets violets were planted: on $22^{\text {th }}$ September 2016 for the first season and 25th September 2017 in the second one in two experiments.

- The beginning of flowers blooming was, in the first season on the 26th January till 20ed April in the first second season on $7^{\text {st }}$ February till to 24th May.

- The offsets violets were planted in the plastic pots; $(25 \mathrm{~cm}$ in diameter) were filled with clay soil and sheets of polyethylene were spread under the pots to control the growth of weeds in the pots.

- A pot experiment was conducted to determine alleviation of salinity stress on vegetative and flowering growth, chemical composition constants and essential oil of viola plants. By using chemical growth method as foliar spray (proline and methyl salicylate (Me Sa) and magnetic field as a modern technology and friendly to the environmentunder saline conditions.

The treatments were conducted as follows:

1. Control was irrigated with tap water $(200 \mathrm{ppm})$.

2. Salinity $1000 \mathrm{ppm}$
3. Salinity $1250 \mathrm{ppm}$

4. Salinity $1500 \mathrm{ppm}$

5. Salinity $1000 \mathrm{ppm}+$ prolin $150 \mathrm{ppm}$

6. Salinity $1000 \mathrm{ppm}+$ methyl salicylate (Me SA) $150 \mathrm{ppm}$

7. Salinity $1000 \mathrm{ppm}+$ magnetic field (150mt)

8. Salinity $1250 \mathrm{ppm}+$ prolin $150 \mathrm{ppm}$

9. Salinity $1250 \mathrm{ppm}+$ methyl salicylate (Me SA) $150 \mathrm{ppm}$

10. Salinity $1250 \mathrm{ppm}+$ magnetic field $(150 \mathrm{mt})$

11. Salinity $1500 \mathrm{ppm}+$ prolin $150 \mathrm{ppm}$

12. Salinity $1500 \mathrm{ppm}+$ methyl salicylate (Me SA) $150 \mathrm{ppm}$

13. Salinity $1500 \mathrm{ppm}+$ magnetic field $(150 \mathrm{mt})$

As (13) treatments for each treatment replicated three times and each replicate continued 3 plots (each plot containing 1 plants).

The sourse of chemical using

Sodium chlorid it was obtained from Agrotec company

\section{Proline}

Proline was obtained from (TechnoGene) 46 Suleiman Johr -Dokki -Giza -EgyptProduct data were as follows:

- L-PROLINE

- For biochemistry

- Assay (exn) min.99\%

- $\mathrm{C} 5 \mathrm{H} 9 \mathrm{NO} 2$

- FW 115.13/ (soluble in water (25c\1623gll)

\section{Methyl salicylate}

Methyl salicylate was obtained from Argo Tec Company-Egypt

Product data were as follows:

- Oxford

- Laboratory reagent

- Methyl salicylate

- For synthesis

- $\mathrm{C} 8 \mathrm{~h} 8$ o 3

- M.W.152.15

- Oxford. lab. chem

- Unit no. 12,1 st floor, Neminath india.Estate.no.6. Navghor Road, vasai (E), Dist.Thane - 401210, india

\section{Magnetic field}

Magnetic field was obtained from Eagle Trading Company) for the trade of screw and steel materials) 33 St- Al - Sabtya- Cairo -Egypt

- Permanent magnet,IS2500 type i3A250 (Manufactured by India Steel Products, Valpaaiso, Indiana) 
- The induction of magnetic field has been $\mathrm{B}=150$ $\mathrm{mT}$, measured with a digital Tesla meter Systron - Donner. In the Physics Department, Faculty of Science, Cairo University.

- This type of magnet is composed of rare earth magnetic material and has a high coercive force. (University of Cambridge, n.d.).

\section{Chemical fertilizers:}

All pots received recommended doses of $(100 \%$ NPK) fertilizers:

- $2.5 \mathrm{~g} / \mathrm{l}$ (pot) calcium superphosphate (15.5\% P2O5) which was added before planting.
- $1.5 \mathrm{~g} /$ (pot) potassium sulphate $(48.5 \% \mathrm{~K} 2 \mathrm{O})$ which was added immediately after thinning. $3.5 \mathrm{~g} /(\mathrm{pot})$ ammonium sulphate (SO4(NH3) $2,20.5 \% \mathrm{~N}$ ) which was divided into three equal portions the first immediately after planting, the second after 30 days from planting and the third after two weeks from the second, according to the recommendations of Agriculture Ministry.

The soil analysis in the present on Table $(1 \mathrm{a}, 1 \mathrm{~b})$ physical and chemical properties of the soil of the experiment were determined at Water and SoilLab. of the Faculty Agriculture (Moshtoher), Benha University, Egypt according to Page et al., (1982)

Table (1a): Soil mechanical properties.

\begin{tabular}{|c|c|c|c|c|}
\hline \multirow{2}{*}{ Texture } & \multicolumn{2}{|c|}{ Sand\% } & \multirow{2}{*}{ Clay \% } & \multirow{2}{*}{ Silt \% } \\
\hline & Fine & Coorse & & \\
\hline Clay & 5.59 & 7.43 & 54.57 & 33.41 \\
\hline
\end{tabular}

Table (1b): Soil chemical properties.

\begin{tabular}{lllllllllllllll}
\hline pH & $\begin{array}{l}\text { E.C } \\
\text { Ds/m }\end{array}$ & So4- $^{--}$ & Cl- & $\mathrm{HCo3}^{-}$ & $\mathrm{Mg}^{++}$ & $\mathrm{Ca}^{++}$ & $\mathrm{K}^{+}$ & $\mathrm{Na}^{+}$ & $\mathrm{N}$ & $\mathrm{P}$ & $\mathrm{K}$ & $\mathrm{Fe}$ & $\mathrm{Mn}$ & $\mathrm{Zn}$ \\
\hline $\mathbf{7 . 3 4}$ & $\mathbf{0 . 6 2}$ & $\mathbf{0 . 8 0}$ & $\mathbf{3 . 4}$ & $\mathbf{2 . 0 0}$ & $\mathbf{1 . 2 0}$ & $\mathbf{2 . 5 0}$ & $\mathbf{1 . 2 3}$ & $\mathbf{1 . 2 7}$ & $\mathbf{9 1 8 . 7}$ & $\mathbf{1 7 . 9}$ & $\mathbf{4 3 1 . 7}$ & $\mathbf{9 4 1 1 . 1}$ & $\mathbf{4 5 0 . 1}$ & $\mathbf{7 2 . 4 3}$ \\
\hline
\end{tabular}

\section{Data recorded:}

- On vegetative growth:

Vegetative growth parameters were measured at the end of each season, the recorded data included:

1- Number of leaves/ plants

2- Fresh weight of leaves (gm).

3- Dry weight of leaves (gm).

4- Leaf area $(\mathrm{cm} 2)$.

5- Fresh weight of roots (gm).

6- Dry weight of roots (gm).

- On flowering

7- Number of flowers / plants.

8- Fresh weight of flowers/ plant (gm).

9- Dry weight of flowers/ plant (gm)

Number of flowers was periodically picked and counted at 15-day interval, therefore total number, fresh weight of flowers /plant, dry weight of flowers /plant were separately calculated per an individual plant.

\section{Chemical composition:}

- Chlorophyll (a and b) contents, (mg/gm FW).

- Nitrogen content in leaves (\% DW).

- Phosphorus content in leaves (\% DW).

- Potassium content in leaves (\% DW).

Chemical determination:

A-Determination of $\mathbf{N}, \mathbf{P}, \mathrm{K}$ percentage

The herbs were oven dried at $70^{\circ} \mathrm{C}$ till constant weight then they were ground in willy mill to fin powder, then weighted $0.2 \mathrm{~g}$ of fine powder and it was digested using a mixture of hydrogen peroxide $\left(\mathrm{H}_{2} \mathrm{O}_{2}\right)$ (4:10), the clear digestion was quantitively to $100 \mathrm{ml}$ volumetric flask in this solution the following elements were determined:
- $\mathrm{N} \%$ was determined by method as described by Horneck and Miller (1998).

- P\% was determined by method as described by Hucker and Catroux (1980).

- K\%was determined by methodas described by Horneck and Hanson (1998).

\section{Pigments content (mg/g of fresh matter)}

\section{A- Chlorophyll $a, b$ in the fresh leaves}

Total chlorophylls as $\mathrm{mg} / 100 \mathrm{~g}$ fresh weight was determined in the leaves of violet according to the method described by AOAC 1990.

The photosynthetic pigments chlorophyll a, b was extracted by methanol alcohol according to Moron (1982) using the spectrophotometer at wavelength of $656,665 \mathrm{~nm}$, respectively.

\section{Volatile oil}

\section{Concrete Extraction with Organic Solvents:}

- according to Guenther [1961]. Concrete \%of leaves and flowers were extracted by using (n-Hexane organic)

- Redistilled n-Hexane of a boiling range of $65-70^{\circ} \mathrm{C}$ was used in the preparation of the concrete oil. Violet leaves and flowers were placed in a large glass container and covered with redistilled nHexane.

- The mixture put at room temperature for 24 hours.

- After filtration, another quantity of n-Hexane was added to the remaining leaves and flowers for 12 hours. 
- By means of a separating funnel. the combined successive n-Hexane extracts were separated from the filtrate (a mixture of $\mathrm{H}_{2} \mathrm{O}$ and $\mathrm{n}$ Hexane).

- Under reduced pressure and temperature not exceeding $35^{\circ} \mathrm{C}$.The $\mathrm{n}$-Hexane layers were hydrated by over anhydrous sodium sulfate, filtered and evaporated.

- The residue (concrete) is a dark brown, waxy and hard mass.

Volatile Oil Extraction:

- $\quad$ According to Guenther [1961]. we used purified absolute ethyl alcohol to extract the violet volatile oil from the obtained concrete.

- $\quad$ By ethyl alcohol, we shook the residue three times and filtered to leaving the waxy matter.

- The ratio of alcohol to concrete oil was $8: 1 \mathrm{v} / \mathrm{w}$.

- $\quad$ Then filtering at temperature $-15^{\circ} \mathrm{C}$. because the filtrate still contained a small number of waxes which were separated. The filtrate was distilled in vacuo at a temperature not exceeding $35^{\circ} \mathrm{C}$. The residue (volatile oil) is brownish, very viscous or semiliquid oil.

- Gas Liquid analysis of violet absolute oil:

*Agilent 6890 gas chromatograph equipped with an Agilent mass spectrometric detector, with a direct capillary interface and fused silica capillary column PAS-5 MS (30m x 0.32mm x 0.25ìm film thickness).

Samples were injected under the following conditions:

- Helium was used as. carrier gas at approximately $1 \mathrm{ml} / \mathrm{min}$., pulsed splitless mode.

- The solvent delay was $3 \mathrm{~min}$. and the injection size were $1.0 \mathrm{ìm}$.

- The mass spectrometric detector was operated in electron impact ionization mode with ionizing energy of $70 \mathrm{EV}$ scanning from m/z 50500.

- The ion source temperature was to $230^{\circ} \mathrm{C}$.

- The electron multiplier voltage was maintained $1250 \mathrm{v}$ above auto tune.
The instrument was manually tuned using perfluorotributylamine (PFTBA).

- The GC temperature program was started at $60^{\circ} \mathrm{C}(2$ min.) they elevated to $300^{\circ} \mathrm{C}$ at the rate of $5^{\circ} \mathrm{C} / \mathrm{min}$. The injector temperature was set at $280^{\circ} \mathrm{C}$, respectively. Wiley and Wiley Nist mass spectral database were used in the identification of the separated peaks.

Statistical analysisthe experimental design was CRD (Complete Randomized Block Design) and the analysis of variance and comparisons between means was done by using the last significant difference (L.S.D) method, according to (Snedecor and Cochranm 1972).

\section{Result and Discussion}

\section{Plant Growth:}

Data in Table $(2,3,4)$ clear the effect of irrigation with saline water one on vegetative characters of violet plants. The data clear that the significant reduction of. No. of leaves/plant, the area of leaves/plant $(\mathrm{cm})$, fresh and dry weight of leaves/plant, number of flowers/plants, flower pedicel length/plant, root fresh and dry weight /plant compared to control was obvious when the rate of saline was increasing from $1000 \mathrm{ppm}$ to 1500ppm.water.

When using the magnetic field with $150 \mathrm{mt}$. there was a marked improvement in growth, followed by second-rate plants sprayed with methyl salicylateand plants treated with proline that were less improved. Compared to the magnetic field or methyl salicylatebut was better than the control.

\section{Chemical Content and Its Oil Ratio}

The resultsin Table $(5,6,7)$ of the chemical content were not very different, and the oil was more important than the results of the vegetative growth but was affected by the increased salinity level.

The best results were when using the magnetic field and then the methyl salicylateand then proline compared to control. 
Table 2. Effect of proline, methyl salicylate and magnetic field under salinity on Viola Odorata linn. plants during the first and second seasons (2016/2017 and 2017/2018) on number of leaves per plant and leaves area $(\mathrm{cm})$.

\begin{tabular}{lllll}
\hline \multirow{2}{*}{ Treatments } & \multicolumn{2}{l}{ Number of leaves/ plants } & \multicolumn{2}{l}{ Leaves area/plant/c.m } \\
\cline { 2 - 5 } & $\mathbf{1}^{\text {st }}$ season & $\mathbf{2}^{\text {st }}$ season & $\mathbf{1}^{\text {nd }}$ season & $\mathbf{2}^{\text {nd }}$ season \\
\hline Control & 11.33 & 11.78 & 23.32 & 19.07 \\
Salinity $1000 \mathrm{ppm}$ & 5.22 & 4.00 & 10.77 & 8.36 \\
Salinity $1250 \mathrm{ppm}$ & 1.55 & 0.89 & 2.79 & 1.65 \\
Salinity $1500 \mathrm{ppm}$ & .66 & 0.44 & 0.98 & .64 \\
Mean & 2.47 & 1.77 & 4.84 & 3.55 \\
Salinity 1000 ppm+ magnetic & 10.66 & 10.67 & 22.87 & 25.46 \\
Salinity1250 ppm+ magnetic & 7.22 & 6.78 & 15.40 & 15.93 \\
Salinity1500 ppm+ magnetic & 6.78 & 6.11 & 14.03 & 15.75 \\
Mean & 8.22 & 7.85 & 17.43 & 17.20 \\
Salinity 1000 ppm+ Me Sa & 7.22 & 7.11 & 16.20 & 15.93 \\
Salinity 1250 ppm+ Me Sa & 4.33 & 3.33 & 6.24 & 7.61 \\
Salinity 1500 ppm+ Me Sa & 3.22 & 2.67 & 4.38 & 4.61 \\
Mean & 4.88 & 4.73 & 8.94 & 9.38 \\
Salinity 1000 ppm+ proline & 6.33 & 5.88 & 14.03 & 13.37 \\
Salinity 1250 ppm+ proline & 2.44 & 2.66 & 4.38 & 3.71 \\
Salinity 1500 ppm+ proline & 1.66 & 1.55 & 2.92 & 2.55 \\
Mean & 3.47 & 3.36 & 7.11 & 6.54 \\
\hline L.S.D. at .05\% & $\mathbf{1 . 2 1}$ & $\mathbf{1 . 3 5}$ & $\mathbf{2 . 4 7}$ & $\mathbf{2 . 9 7}$ \\
\hline L.S.D. at .01\% & $\mathbf{1 . 6 4}$ & $\mathbf{1 . 8 3}$ & $\mathbf{3 . 3 4}$ & $\mathbf{4 . 0 2}$ \\
\hline
\end{tabular}

Table 3. Effect of proline, methyl salicylate and magnetic field under salinity on Viola Odorata Linn. plants during the first and second seasons (2016/2017 and 2017/2018) on fresh and dry weights of leaves/plant $(\mathrm{g})$

\begin{tabular}{|c|c|c|c|c|}
\hline \multirow{2}{*}{ Treatments } & \multicolumn{2}{|c|}{ Fresh weight/Leaves } & \multicolumn{2}{|c|}{ dry weights of leaves } \\
\hline & $1^{\text {st }}$ season & $2^{\text {nd }}$ season & $1^{\text {st }}$ season & $2^{\text {nd }}$ season \\
\hline Control & 20.60 & 21.68 & 3.99 & 4.13 \\
\hline Salinity 1000 ppm & 8.83 & 6.38 & 1.52 & 1.39 \\
\hline Salinity $1250 \mathrm{ppm}$ & 2.21 & 1.44 & 0.20 & 0.25 \\
\hline Salinity $1500 \mathrm{ppm}$ & 0.43 & 0.46 & 0.05 & 0.07 \\
\hline Mean & 3.82 & 2.76 & 0.59 & 0.78 \\
\hline Salinity 1000 ppm+ magnetic & 20.52 & 19.95 & 3.59 & 4.15 \\
\hline Salinity 1250 ppm+ magnetic & 13.75 & 13.26 & 2.13 & 2.50 \\
\hline Salinity $1500 \mathrm{ppm}+$ magnetic & 12.15 & 11.60 & 2.06 & 2.41 \\
\hline Mean & 14.97 & 14.93 & 2.59 & 2.93 \\
\hline Salinity 1000 ppm+ Me Sa & 13.57 & 12.40 & 2.28 & 2.68 \\
\hline Salinity $1250 \mathrm{ppm}+\mathrm{Me} \mathrm{Sa}$ & 6.77 & 5.63 & 1.07 & 1.16 \\
\hline Salinity $1500 \mathrm{ppm}+\mathrm{Me} \mathrm{Sa}$ & 5.61 & 3.18 & 0.68 & 0.92 \\
\hline 7.74Mean & 8.65 & 7.07 & 1.34 & 1.58 \\
\hline Salinity $1000 \mathrm{ppm}+$ proline & 11.23 & 10.17 & 1.84 & 2.01 \\
\hline Salinity $1250 \mathrm{ppm}+$ proline & 3.22 & 4.51 & 0.58 & 0.65 \\
\hline Salinity $1500 \mathrm{ppm}+$ proline & 2.63 & 1.28 & 0.4 & 0.25 \\
\hline Mean & 5.72 & 5.32 & 0.94 & 0.97 \\
\hline L.S.D. at $0.05 \%$ & 2.34 & 2.25 & .45 & 0.45 \\
\hline L.S.D. at $0.01 \%$ & 3.17 & 3.05 & .61 & 0.60 \\
\hline
\end{tabular}


Table 4. effect of proline, methyl salicylate and magnetic field under salinity on Viola Odorata Linn. plants during the first and second seasons (2016/2017 and 2017/2018) on number of flower/plant (g) and Pedicel length $(\mathrm{cm}) /$ plant

\begin{tabular}{|c|c|c|c|c|}
\hline \multirow{2}{*}{ Treatments } & \multicolumn{2}{|c|}{ Number of flower/plants } & \multicolumn{2}{|c|}{ Pedicel length $(\mathrm{cm}) /$ plant } \\
\hline & $1^{\text {st }}$ season & $2^{\text {nd }}$ season & $1^{\mathrm{s}}$ season & $2^{\text {nd }}$ season \\
\hline Control & 9.22 & 9.33 & 6.24 & 6.15 \\
\hline Salinity 1000 ppm & 2.44 & 1.78 & 2.91 & 2.62 \\
\hline Salinity $1250 \mathrm{ppm}$ & 0.22 & .22 & 1.20 & 1.06 \\
\hline Salinity $1500 \mathrm{ppm}$ & 0.00 & 0.11 & 0.00 & 0.03 \\
\hline Mean & 0.88 & 0.70 & & \\
\hline Salinity 1000 ppm+ magnetic & 8.66 & 9.33 & 6.12 & 6.02 \\
\hline Salinity $1250 \mathrm{ppm}+$ magnetic & 5.89 & 4.66 & 4.02 & 3.91 \\
\hline Salinity 1500 ppm + magnetic & 3.66 & 3.67 & 3.88 & 3.74 \\
\hline Mean & 6.10 & 5.88 & & \\
\hline Salinity 1000 ppm+ Me Sa & 7.66 & 5.67 & 4.46 & 4.14 \\
\hline Salinity $1250 \mathrm{ppm}+\mathrm{Me} \mathrm{Sa}$ & 1.44 & 1.78 & 2.03 & 1.79 \\
\hline Salinity $1500 \mathrm{ppm}+\mathrm{Me} \mathrm{Sa}$ & .77 & 1.22 & 2.01 & 1.82 \\
\hline Mean & 3.29 & 2.89 & & \\
\hline Salinity $1000 \mathrm{ppm}+$ proline & 2.99 & 2.89 & 3.18 & 3.03 \\
\hline Salinity $1250 \mathrm{ppm}+$ proline & .66 & .66 & 1.71 & 1.41 \\
\hline Salinity $1500 \mathrm{ppm}+$ proline & 0.22 & 0.22 & 1.37 & 1.21 \\
\hline Mean & 1.29 & 1.25 & & \\
\hline L.S.D. at $0.05 \%$ & 1.57 & 1.19 & 0.30 & 0.35 \\
\hline L.S.D. at 0.01\% & 2.12 & 1.61 & 0.40 & 0.48 \\
\hline
\end{tabular}

Table 5. Effect of proline, methyl salicylate and magnetic field under salinity on viola Odorata Linn. plants during the first and second seasons (2016/2017 and 2017/2018) on fresh and dry weight of flower/plant (g)

\begin{tabular}{|c|c|c|c|c|}
\hline \multirow{2}{*}{ Treatments } & \multicolumn{2}{|c|}{ Fresh weight flower/plant/g } & \multicolumn{2}{|c|}{ Dry weight flower/plant/g } \\
\hline & $1^{\text {st }}$ season & $2^{\text {nd }}$ season & $1^{\text {st }}$ season & $2^{\text {nd }}$ season \\
\hline Control & 1.98 & 2.15 & 0.52 & 0.57 \\
\hline Salinity 1000 ppm & 0.50 & 0.35 & 0.12 & 0.10 \\
\hline Salinity $1250 \mathrm{ppm}$ & 0.03 & 0.03 & 0.01 & 0.00 \\
\hline Salinity 1500 ppm & 0.00 & 0.01 & 0.00 & 0.00 \\
\hline Mean & 0.17 & 0.13 & 0.04 & 0.10 \\
\hline Salinity 1000 ppm+ magnetic & 1.83 & 1.98 & 0.50 & 0.55 \\
\hline Salinity 1250 ppm+ magnetic & 1.36 & 1.05 & $0 . .35$ & 0.26 \\
\hline Salinity 1500 ppm + magnetic & .78 & 0.85 & $0 . .21$ & 0.16 \\
\hline Mean & 1.32 & 1.29 & 0.35 & 0.32 \\
\hline Salinity 1000 ppm+ Me Sa & 1.62 & 1.24 & 0.42 & 0.35 \\
\hline Salinity 1250 ppm+ Me Sa & .15 & 0.19 & $0 . .08$ & 0.09 \\
\hline Salinity 1500 ppm + Me Sa & .29 & 0.35 & 0.03 & 0.06 \\
\hline Mean & 0.68 & 0.59 & 0.17 & 0.16 \\
\hline Salinity $1000 \mathrm{ppm}+$ proline & 0.66 & 0.65 & 0.17 & 0.16 \\
\hline Salinity $1250 \mathrm{ppm}+$ proline & 0.50 & 0.10 & 0.03 & 0.04 \\
\hline Salinity 1500 ppm + proline & 0.4 & 0.04 & 0.01 & 0.01 \\
\hline Mean & 0.52 & 0.26 & 0.08 & .07 \\
\hline L.S.D. 0.05\% & 0.25 & 0.27 & 0.050 & $\mathbf{0 . 0 5 3}$ \\
\hline L.S.D. 0.01\% & 0.33 & 0.36 & 0.067 & 0.070 \\
\hline
\end{tabular}


Table 6. Effect of proline, methyl salicylate and magnetic field under salinity on Viola Odorata Linn. plants during the first and second seasons (2016/2017 and 2017/2018) on fresh and dry weight of roots/plant (g)

\begin{tabular}{|c|c|c|c|c|}
\hline \multirow[b]{2}{*}{ Treatments } & \multicolumn{2}{|c|}{ Fresh weight of root/plant } & \multicolumn{2}{|c|}{ Dry weight of root/plant } \\
\hline & $1^{\text {st }}$ season & $2^{\text {nd }}$ season & $2^{\text {nd }}$ season & $2^{\text {nd }}$ season \\
\hline Control & 2.92 & 3.61 & 1.53 & 1.89 \\
\hline Salinity 1000 ppm & 1.12 & 1.00 & 0.54 & 0.54 \\
\hline Salinity 1250 ppm & 0.37 & 0.20 & 0.17 & 0.10 \\
\hline Salinity 1500 ppm & 0.08 & 0.08 & 0.04 & 0.04 \\
\hline Mean & 0.52 & 0.42 & 0.25 & 0.22 \\
\hline Salinity 1000 ppm+ magnetic & 2.61 & 3.50 & 1.41 & 1.58 \\
\hline Salinity 1250 ppm+ magnetic & 1.66 & 2.15 & 0.90 & 0.90 \\
\hline Salinity 1500 ppm + magnetic & 1.27 & 1.63 & 0.69 & 0.86 \\
\hline Mean & 1.69 & 2.42 & 1 & 1.11 \\
\hline Salinity 1000 ppm+ Me Sa & 1.78 & 2.99 & 0.96 & 1.14 \\
\hline Salinity 1250 ppm+ Me Sa & 0.81 & 0.83 & 0.53 & 0.44 \\
\hline Salinity 1500 ppm + Me Sa & 1.01 & .64 & $0 . .42$ & 0.34 \\
\hline Mean & 1.2 & 1.48 & 0.63 & 0.64 \\
\hline Salinity 1000 ppm+ proline & 1.26 & 1.57 & 0.63 & 0.84 \\
\hline Salinity 1250 ppm+ proline & 0.68 & 0.35 & 0.36 & 0.54 \\
\hline Salinity 1500 ppm + proline & 0.45 & 0.20 & 0.25 & 0.18 \\
\hline Mean & 0.79 & 0.70 & 0.41 & 0.52 \\
\hline L.S.D. at $0.05 \%$ & $\mathbf{0 . 3 3}$ & 1.78 & 0.1 & 0.18 \\
\hline L.S.D. at $0.01 \%$ & 0.45 & 2.41 & 0.22 & 0.25 \\
\hline
\end{tabular}

Table 7. Effect of proline, methyl salicylate and magnetic field under salinity on Viola Odorata linn. plants during the first and second seasons (2016/2017 and 2017/2018) on Nitrogen, Potassium and Phosphorus percentage.

\begin{tabular}{|c|c|c|c|c|c|c|}
\hline \multirow{2}{*}{ Treatments } & \multicolumn{2}{|c|}{ Nitrogen $\%$} & \multicolumn{2}{|c|}{ Potassium\% } & \multicolumn{2}{|c|}{ Phosphorus\% } \\
\hline & $1^{\text {st }}$ season & $2^{\text {nd }}$ sean & $1^{\text {st }}$ seasn & $2^{\text {nd }}$ season & $1^{\text {stseason }}$ & $2^{\text {nd }}$ season \\
\hline Control & 1.77 & 1.68 & 0.89 & 0.93 & 1.42 & 1.44 \\
\hline Salinity 1000 ppm & 0.51 & 0.48 & 0.36 & 0.29 & 0.46 & 0.44 \\
\hline Salinity 1250 ppm & 0.13 & 0.09 & 0.07 & 0.05 & 0.10 & 0.07 \\
\hline Salinity 1500 ppm & 0.02 & 0.04 & 0.01 & 0.01 & 0.01 & 0.02 \\
\hline Mean & 0.22 & 0.20 & 0.14 & 0.11 & 0.19 & 0.17 \\
\hline Salinity 1000 ppm+ magnetic & 1.77 & 1.39 & 0.79 & 0.88 & 1.35 & 1.36 \\
\hline Salinity 1250 ppm+ magnetic & 1.37 & 0.98 & 0.53 & 0.55 & 0.87 & 0.81 \\
\hline $\begin{array}{llll}\text { Salinity } & 1500 & \text { ppm } & + \\
\text { magnetic } & & & \end{array}$ & 0.93 & 0.88 & 0.52 & 0.49 & 0.77 & 0.78 \\
\hline Mean & 1.35 & 1.08 & 0.61 & 0.64 & 0.99 & 0.98 \\
\hline Salinity 1000 ppm+ Me Sa & 1.36 & 0.89 & 0.54 & 0.88 & 0.89 & 0.88 \\
\hline Salinity 1250 ppm+ Me Sa & 0.34 & 0.46 & 0.22 & 0.24 & 0.43 & 0.37 \\
\hline Salinity 1500 ppm + Me Sa & 0.30 & 0.33 & 0.28 & 0.20 & 0.34 & 0.30 \\
\hline Mean & 0.66 & 0.56 & 0.34 & 0.44 & 0.55 & 0.51 \\
\hline Salinity 1000 ppm+ proline & 0.70 & 0.71 & 0.46 & 0.43 & 0.70 & 0.66 \\
\hline Salinity 1250 ppm+ proline & 0.29 & 0.23 & 0.16 & 0.12 & 0.27 & 0.20 \\
\hline Salinity 1500 ppm + proline & 0.22 & 0.09 & 0.09 & 0.05 & 0.21 & 0.09 \\
\hline Mean & 0.40 & 0.34 & 0.23 & 0.2 & 0.39 & 0.31 \\
\hline L.S.D. at $0.05 \%$ & 0.18 & 0.22 & 0.08 & 0.09 & 0.18 & 0.14 \\
\hline L.S.D. at $0.01 \%$ & 0.25 & 0.30 & 0.12 & 0.13 & 0.25 & 0.19 \\
\hline
\end{tabular}


Table 8. effect of proline, methyl salicylate and magnetic field under salinity on Viola Odorata linn. plants during the first and second seasons (2016/2017 and 2017/2018) on percentage of concrete in leaves and flowers .

\begin{tabular}{|c|c|c|c|c|}
\hline \multirow{2}{*}{ Treatments } & \multicolumn{2}{|l|}{ leaves } & \multicolumn{2}{|l|}{ flowers } \\
\hline & $\mathbf{1}^{\text {st }}$ season & $2^{\text {nd }}$ season & $\mathbf{1}^{\text {st }}$ season & $2^{\text {nd }}$ season \\
\hline Control & 0.018 & 0.016 & 0.023 & 0.025 \\
\hline Salinity 1000 ppm & 0.008 & 0.006 & 0.009 & 0.006 \\
\hline Salinity 1250 ppm & 0.003 & 0.001 & 0.004 & 0.004 \\
\hline Salinity 1500 ppm & 0.000 & 0.000 & 0.000 & 0.000 \\
\hline Mean & 0.0003 & 0.002 & 0.004 & 0.003 \\
\hline Salinity 1000 ppm+ magnetic & 0.016 & 0.016 & 0.019 & 0.022 \\
\hline Salinity 1250 ppm+ magnetic & 0.010 & 0.011 & 0.015 & 0.012 \\
\hline Salinity 1500 ppm + magnetic & 0.009 & 0.009 & 0.010 & 0.010 \\
\hline Mean & 0.011 & 0.012 & 0.014 & 0.014 \\
\hline Salinity 1000 ppm+ Me Sa & 0.009 & 0.008 & 0.014 & 0.010 \\
\hline Salinity 1250 ppm+ Me Sa & 0.006 & 0.005 & 0.005 & 0.005 \\
\hline Salinity 1500 ppm + Me Sa & 0.004 & 0.004 & 0.003 & 0.004 \\
\hline Mean & 0.006 & 0.005 & 0.007 & 0.006 \\
\hline Salinity 1000 ppm+ proline & 0.007 & 0.006 & 0.007 & 0.007 \\
\hline Salinity 1250 ppm+ proline & 0.003 & 0.003 & 0.003 & 0.004 \\
\hline Salinity 1500 ppm + proline & 0.002 & 0.002 & 0.001 & 0.000 \\
\hline Mean & 0.004 & 0.003 & 0.003 & 0.003 \\
\hline L.S.D. 0.05\% & 0.003 & 0.002 & 0.003 & 0.004 \\
\hline L.S.D. 0.01\% & 0.004 & 0.003 & 0.004 & 0.005 \\
\hline
\end{tabular}

This results harmony with previous investigations likeRobabeh and Rahim (2018) on Aloe Veraindicated that, salinity stress has significant negative effect on the plant's morphological traits, such as its weight, leaf length, leaf weight, gel weight, root length; and biochemical traits such as total phenol, total soluble sucrose, glucose and fructose, Acosta Motoset al., (2017) informed that, salinity as abiotic stress is a permanent major threat to the agriculture industry worldwide and usually associated with morphological (reduced growth and productivity), physiological (reduction of gas exchange parameters and homeostasis), and biochemical (oxidative stress with elevated reactive oxygen species content) responses. Hemalatha et al., (2017) cleared that, salinity stress reduces plant yield by affecting physiology as well as biochemistry of plant.

The results of the previous tables showed a remarkable response to the use of the magnetic field under irrigation conditions in salt water. This was also confirmed by many scientists such as.Kataria $\boldsymbol{e t}$ al., (2017)cleared that, static magnetic treatment has caused a significant increase in the height, leaf area and dry weight of plants subjected to salt stress.Dhawi (2014) mentioned that, magnetic water affect macromolecules uptake, the accumulation of the elements in each plant and in the same plant different parts which led to a noticeable increases content of $\mathrm{Mg}, \mathrm{Fe}$ and $\mathrm{Cu}$ in grain and $\mathrm{P}, \mathrm{Ca}, \mathrm{K}$ and $\mathrm{Zn}$, also the magnetic water increased ions content significantly with prolonged exposure treatment may irreversibly affect cell membrane permeability leading to increase element uptake.

It also noted previous research into the role of methyl and proline in reducing the effect of salinity on plant growth as reflected in the results of the current study , such as Hakimeh Darvizheh and Mohsen Zavareh (2018) demonstrated that, proline application had significant impact on all traits under water stress conditions. The foliar application of $100 \mathrm{mg} / \mathrm{L}$ proline resulted to improvement of growth and alleviate of water stress damages. overall, application of $100 \mathrm{mg} / \mathrm{L}$ proline would be recommendable to reach the maximum yield of German chamomile in various water deficit circumstance, Monika Grzeszczuket al., (2018)on Salvia coccineastudied that, exogenous application of SA increased the number of branches, fresh herbal weight, and total chlorophyll content vs control plants.

\section{References}

Payal Mittal, Vikas Gupta , Manish Goswami , Nishant Thakur and Praveen Bansal (2015) phytochemical and pharmacological potential of viola odorata. IJP ,Vol. 2, Issue 5

Aziz Eman ,E., Al-Amier, H. and Craker Lyle, E. (2008) Influence of Salt Stress on Growth and Essential Oil Production in Peppermint, 
Pennyroyal, and Apple Mint. J. Herb. Spic. Med. Plants., 14, (1, 2) 77 - 87.

Ali, Q.; M. Ashraf And H.R. Athar (2007) Exogenously applied proline at different growth stages enhances growth of two maize cultivars grown under water deficit conditions. Pak. J. Bot., 39(4): 1133-1144.

Fung, R.W.M., Wang, C.Y., Smith, D.L., Gross, K.C., Tian, M.S(2004)MeSA and MeJA increase steady-state transcript levels of alternative oxidase and resistance against chilling injury in sweet peppers (Capsicum annuum L.).Plant Sci. 166: 711-719

Ashwini h. Gudigar (2013) effect of magnetic treatment on irrigation water quality, soil properties and growth of sunflower crop. Thesis Master of Science. University of agricultural sciences, dharwad

Okuma E.; Y. Murakami; Y. Shimoishi; M. Tada And Y. Murata (2004). Effect of exogenous application of proline and betain on the growth of tobacco cultured cells under saline conditions. Soil. Sci. Plant Nutr., 50(8):1301-1305.

Vlot AC, Liu PP, Cameron RK (2008) Identification of likely Orthologs of tobacco salicylic acid-binding protein 2 and their role in Systemic acquired resistance in Arabidopsis thaliana. The Plant Journal 56, 445-456.

K.N. Guruprasad1, M.B. Shine1 and Juhie Joshi1(2014) Impact of Magnetic 9 Aladjadjiyan, A, 2010. Influence of stationary magnetic field on lentil seeds. Int. Agrophysics,24:321-324. -Field on Crop Plants. School of Life Sciences, Devi Ahilya University, India.

Esitken, A, and Turan M, (2004). Alternating magnetic field effects on yield and plant nutrient element composition of Strawberry (Fragaria ananassa cv. Camarosa). Soil and Plant Sci., 54:135-139.

Page, A.L., R. Miller and H. Keeney, (1982.) Methodsof Soil Analysis. Part 2, 2ndEd., Am. Soc. Agronomy,Inc. Mad. Wisconsin, USA.
Horneck, D.A. and D. Hanson,(1998) Determination of Potassium and Sodium by Flame Emission Spectrophotometry. In hand book of reference methods for plant analysis, Kolra, Y.P. (ed). 153-155.

Hucker, T. and G. Catroux, (1980)Phosphorus insewage ridge and animal's wastes slurries. Proceeding of the EEC Seminar, Haren (Gr):

Guenther, E., (1961) The Essential Oils. Vol.(1v). van Nostrand co. New York

A.O.A.C., (1990.) Official Methods of Analysis ofAssociation of Official Analytical Chemists. Pub.A.O.A.C. INC. Suite 400, 22201 USA Fifteenth Ed.pp: 62-63, 236 and 877-878.

Robabeh Asghari and Rahim Ahmadvand (2018) Salinity stress and its impact on morphophysiological characteristics of Aloe Vera.Pertanika J. Trop. Agric. Sci. 41 (1): 411 422.

Hemalatha, G., Renugadevi, J. and Evera, T. (2017) Studies on seed priming with hydrogen peroxide for mitigating salt stress in rice. Int. J. Curr. Microbiol. App. Sci., 6(6): 691-695.

Kataria, S., Baghel, B., Guruprasad K.N (2017) Pretreatment of seeds with static magnetic field improves germination and early growth characteristics under salt stress in maize and soybean. Bio catalysis and agricultural biotechnology. 10, 83-90.

Dhawi, F. (2014) Why magnetic fields are used to enhance a plants growth and productivity? Annual Research \& review in Biology.,4 (6): 886-896.

Hakimeh Darvizheh and Mohsen Zavareh (2018)Effects of proline foliar application on alleviation of water deficit in German chamomile Agro. J. Vol. 14, Issue 1.Spring 2018, Page 3343.

Monika Grzeszczuk, Piotr Salachna, and Edward Meller (2018) Changes in photosynthetic pigments, total phenolic content, and antioxidant activity of Salvia coccinea Induced by Exogenous salicylic acid and soil salinity.23, molecules23061296. 